\title{
Infection and invasion mechanisms of Trypanosoma cruzi in the congenital transmission of Chagas' disease: A proposal
}

\author{
Ulrike Kemmerlinga, ${ }^{\mathrm{a}}{ }^{*}{ }^{*}$, Cleo Bosco and Norbel Galanti ${ }^{\mathrm{b}}$ \\ a Program of Anatomy and Developmental Biology, Institute for Biomedical Science, Faculty of Medicine, University of Chile, Santiago, Región Metropolitana, Chile \\ b Program of Cellular and Molecular Biology, Institute for Biomedical Science, Faculty of Medicine, University of Chile, Santiago, Región Metropolitana, Chile \\ c Department of Stomatology, Faculty of Health Sciences, University of Talca, Talca, Región del Maule, Chile
}

\begin{abstract}
Chagas' disease is produced by the haemophlagelated protozoan Trypanosoma cruzi and transmitted by haematophages insects such as Triatoma infestans (vinchuca). Due to vector control, congenital transmission gains importance and is responsible for the presence and expansion of this disease in non-endemic areas.

The mechanisms of congenital infection are uncertain. It has been suggested that the parasite reaches the fetus through the bloodstream by crossing the placental barrier, and that congenital Chagas' disease is the result of complex interactions between the immune response, placental factors, and the parasite's characteristics.

We review the cellular and molecular mechanisms of infection and invasion of the parasite and how immune and placental factors may modulate this process. Finally, we propose a possible model for the vertical transmission of Chagas' disease.
\end{abstract}

Key terms: congenital Chagas' disease, mechanism of infection, tissue invasion.

Dr. Gustavo Hoecker: Your definitive departure was sorrowful for all your friends.

However, we also feel proud and happy for the opportunity to have had you among us. It is not possible to forget your imposing presence. Your acute intelligence, sharp and deep, always inquiring, always producing surprising and unexpected answers, in a context of enormous sympathy and humor. To talk with you was always a moment of learning, of enthusiasm and of looking for new aspects of the same old problem. Today, Science is measured by the number of approved projects and the impact index of publications. Time given over to thinking and reasoning, as well as the possibility of playing with ideas, is considered by many as a wasted. Gone are the happy days in which thinking was the main task of a scientist. You were a Professor, a Teacher, a person always giving time for reading the scientific literature, for thinking and for sharing your knowledge and ideas. You were always ready to listen. Dear Gustavo: Thanks for giving us the opportunity of your friendship.

\section{CHAGAS` DISEASE}

One of the major health problems in Latin America is Chagas' disease, caused by different clones of the flagellated protozoan Trypanosoma cruzi, affecting more than 18 million people (WHO Expert Committee, 2002) in poor and marginal populations in Central and South America. At present it is one the major public health concerns in Latin America. In vector related diseases, it is second to malaria in prevalence and mortality (WHO Expert Committee, 2002). Chagas' disease is one of the "Neglected Tropical Diseases" that have received little attention and resources despite their magnitude and impact on both economic development and quality of life. However, in recent years, growing attention has been focused on neglected tropical diseases as both a public health issue and a human rights issue. (www.who.int/hhr). The disease spreads from southern United States through southern Argentina and Chile. At least twenty-eight million people are at risk of exposure to infection, with an estimated total of fifteen million cases.

Of these, Chile contributes with an estimated 150,000 presumably infected cases. On the other hand, according to reports from the World Health Organization, mortality rates vary from 8 to $12 \%$ depending on the country studied, age, patients' physiologic status, and modality of treatment (WHO Expert Committee, 2002).

\section{CHAGAS' DISEASE AND ITS AGENTS}

T. cruzi presents an indirect life cycle, with haematophagous insects (Triatomids) as intermediary hosts, and mammals, including man, as definitive hosts (de Souza, et al 2002). The main T. cruzi triatomid vectors in South America are Triatoma infestans ("vinchuca"), Rhodnius prolixus, and Panstrongylus megistus. In addition to $T$. infestans (domiciliary cycle), Mepraia spinolai and Mepraia gajardoi (sylvatic cycle) are also found in Chile (WHO Expert Committee, 2002).

Disease transmission is mainly produced by the bite of $T$. cruzi infected insects that, upon feeding on mammal blood, deposit feces contaminated with infecting metacyclic trypomastigotes on the skin. The parasites then enter the blood stream through the skin by a mechanism facilitated by self-inflicted scratching and proteolytic enzymes found in the insect's saliva (Amino, et al. 2002). Upon entering the blood stream, trypomastigotes are phagocytosed by macrophages and leucocytes, thus differentiating into amastigotes, the obligate cytoplasmatic form of replication. After a certain number of replications, amastigotes differentiate into trypomastigotes and then escape from

* Corresponding Author: Tel.: 56-2-9786261, Fax: 56-2-9786264; e-mail: ukemmerling@med.uchile.cl

Received: July 22, 2009. In revised version: June 11, 2010. Accepted: July 6, 2010 
these cells into circulation, heading into target tissues such as myocardium, skeletal muscle, smooth visceral muscle, glial cells of the nervous system, and the placenta. Other important forms of infection are blood transfusions, organ transplants (10\% of cases) (Prata, 2001; Coura, 2007), oral infection through the ingestion of contaminated foods (Coura, 2006; Yoshida,), and transplacental transmission in Chagasic mothers (Prata, 2001; Coura, 2007; Fragata Filho, et al 2008). These alternative forms of infection have progressively gained epidemiologic importance (Prata, 2001; Coura, 2007; Yoshida, 2008).

T. cruzi is basically divided into two divergent genetic groups or lineages (T. cruzi I y II), that supposedly belong to two different ecologic environments (Di Noia, et al 2002; Freitas, et al 2005; Manoel-Caetano and Silva 2007; Cerqueira, et al 2008). T. cruzi I is mainly detected in the sylvatic cycle, infecting American marsupials and mammals, whereas T. cruzi II is mainly present in the domestic cycle and associated with human pathogenesis (Di Noia, et al 2002; Freitas, et al 2005; Manoel-Caetano and Silva 2007).

The parasite's biological cycle includes three morphologic aspects characterized by the relative positions of the flagellum, kinetoplast, and nucleus (Prata, 2001): 1) Trypomastigotes: 20 micrometers in length, sub-terminal kinetoplast, and fusiform. They constitute the parasite's infecting and non-replicative forms, which are found in mammal blood and in the posterior intestine of triatomids. In mammals, this is the cellular form that disseminates infection through blood. 2) Epimastigotes: Also 20 micrometers in length, kinetoplast anterior to the nucleus, and fusiform. They represent the parasite's form of replication in the anterior intestine of the triatomid, and the predominant form in axenic cultures. 3) Amastigotes: approximately 2 micrometers in diameter, round, with no emergent flagellum. It multiplies within the host mammal's cells until they rupture free (after 8-9 cell divisions). Before their release from the host cells, amastigotes differentiate back into trypomastigotes that invade the blood stream; they may then enter any other nucleated cell. Amastigotes can be grown in cell cultures inside muscle cells, fibroblasts, and macrophages (Morello, et al 1987; Burleigh and Andrews 1995; Yoshida, 2006), from which infecting forms of T. cruzi (trypomastigotes) may be harvested. Chagas' disease develops in three phases. First the acute phase, immediately post infection, with high levels of parasitemia and symptoms in only some patients (regional lymph node enlargement, bipalpebral unilateral edema or Romana's sign, and characteristic electrocardiogram alterations). In most cases, acute infection is not accompanied by clinical findings, thus moving on to the latent phase that can last for months or years (Soares, et al 2001). The chronic phase, present in $30 \%$ of infected individuals, is associated with mega colon, mega esophagus, degeneration of the autonomous nervous system, arrhythmias, and abnormal growth of the heart with progressive insufficiency (Prata, 2001) and evident negative impact on the patient's health. In this phase the disease can be handicapping, and either be the concurrent or the direct cause of death. The course of the disease depends on diverse factors: parasite load at the site of inoculation, both the parasite's genetic group and strain, whether it is an infection de novo or re-infection, the host's immunologic status, and the type of vector (triatomid) (Coura, 2007).

\section{CONGENITAL CHAGAS' DISEASE}

In the past few years congenital transmission of T. cruzi has increasingly become more important, and partly responsible for the "globalization of Chagas' disease" (Schmunis, 2007), constituting a public health problem of increasing relevance (Torrico et al 2005; Carlier et al 2005, Lescoure et al 2008). As a result of vector control (triatomids), the number of new cases per year has greatly decreased, from 700000 in 1990 to 41000 in 2006. Nonetheless, the number of congenital Chagas cases was 14,385 in 2006, which is why this form of transmission is of growing importance epidemiologically (WHO Expert Committee, 2002). Children and women are disproportionately affected by neglected tropical diseases (such as Chagas'disease) and may face additional barriers to seeking and receiving treatment ( $w$ ww.who.int/hhr). Serologic prevalence among pregnant women can reach $80 \%$, and rates of congenital infection vary from 1-21\% (Kirchhoff, 1993; Blanco, et al 2000; Shippey III, et al 2005, Torrico, et al 2005, Burgos, et al 2007). Rates of congenital transmission vary from $1 \%$ in Brazil to $4.12 \%$ in Argentina, Chile, and Paraguay. The cure for chronic Chagas' disease was recently reported in mice, following two treatments with benznidazole, which induces an antigen-independent CD8+T cell memory (Bustamante, et al 2008). Unfortunately, benznidazole is a toxic drug (Maya, et al 2007; Castro, et al 2006) that cannot be used in pregnant women. Therefore, in the event that the aforementioned treatment is effective in humans, vertical transmission cannot be prevented due to the toxicity and teratogenicity of the drugs available to treat Chagas' disease (Castro, et al 2006).

The requirements in order to consider a Chagas case as congenital are the following: 1) T. cruzi seropositive mother; 2) Postpartum detection of parasites in newborns; or 3) Detection of parasites or specific anti-T.cruzi antibodies (generated by the child) at a later time, only if contamination due to transfusion or vector transmission can be ruled out (Carlier, 2005). Congenital T. cruzi infection is associated with premature labor, low birth weight, and still births (Bittencourt, 1976; Altemani, 2000; Shippey III, et al 2005). About $50 \%$ of premature babies born to mothers with Chagas do not survive (Shippey SH III, et al 2005). Pathophysiology of congenital infection is unknown (WHO Expert Committee 2002, Shippey SH III, et al 2005). It has been suggested that the parasite reaches the fetus by crossing the placental barrier (Bittencourt, 1976; Andrade, 1982; Nisida, 1999; Carlier, 2005). Nevertheless, knowledge of the cellular and molecular mechanisms of transplacental infection is scarce (WHO Expert Committee 2002; Shippey III, et al 2005; Burgos, et al 2007). It is thought that congenital Chagas' disease is product of a complex interaction among the maternal immune response, placental factors, and the characteristics of the parasite (Carlier, 2005; Burgos, et al 2007). The placenta is the principal site for the exchange of nutrients and gases between mother and fetus (Syme, et al 2004; Moore and Persaud 2004). In addition, it plays an important role in hormone, peptide, and steroid synthesis that are fundamental for a successful pregnancy (Syme, et al 2004). The placenta is composed of a fetal portion, developed from the chorion frondosum, and a maternal portion, or basal decidua, which originates from the endometrium (Moore and Persaud 2004; Cross, 2006). The human placenta presents a 
maternofetal hemo-monochorial barrier or "membrane" according to the Grosser classification (Benirschke, 2006). This type of maternofetal barrier is composed of extra fetal tissue that separates maternal blood in the intervillous space from that of the fetus. Until week 20 of gestation this barrier is composed of syncytiotrophoblast, cytotrophoblast, connective tissue in the villous stroma of chorionic villi, and fetal capillary endothelium (Figure 1AB). After week 20, the placenta undergoes adaptations that improve metabolic exchange, cytotrophoblastic cells diminish, and the nuclei of syncytiotrophoblast cells group together forming nodes (Figure 1C-D). This restructuring favors metabolic exchange due to the formation of thin cytoplasmatic areas devoid of nuclei, so that fetal capillaries come close to the syncytiotrophoblast and thus the placental membrane transforms into a thinner barrier (Moore and Persaud, 2004).
A

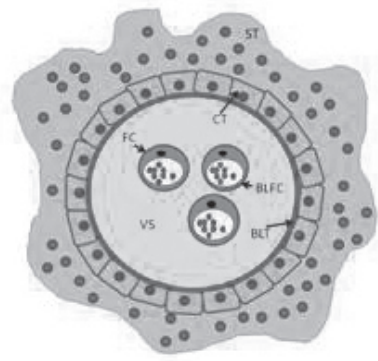

C

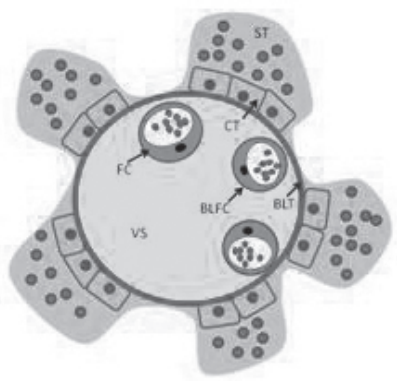

B

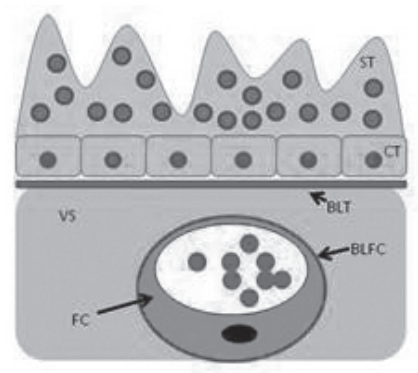

D

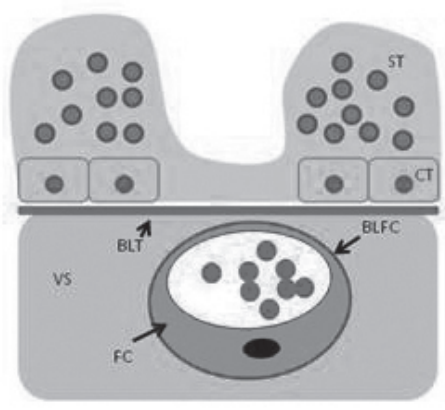

$\mathbf{E}$

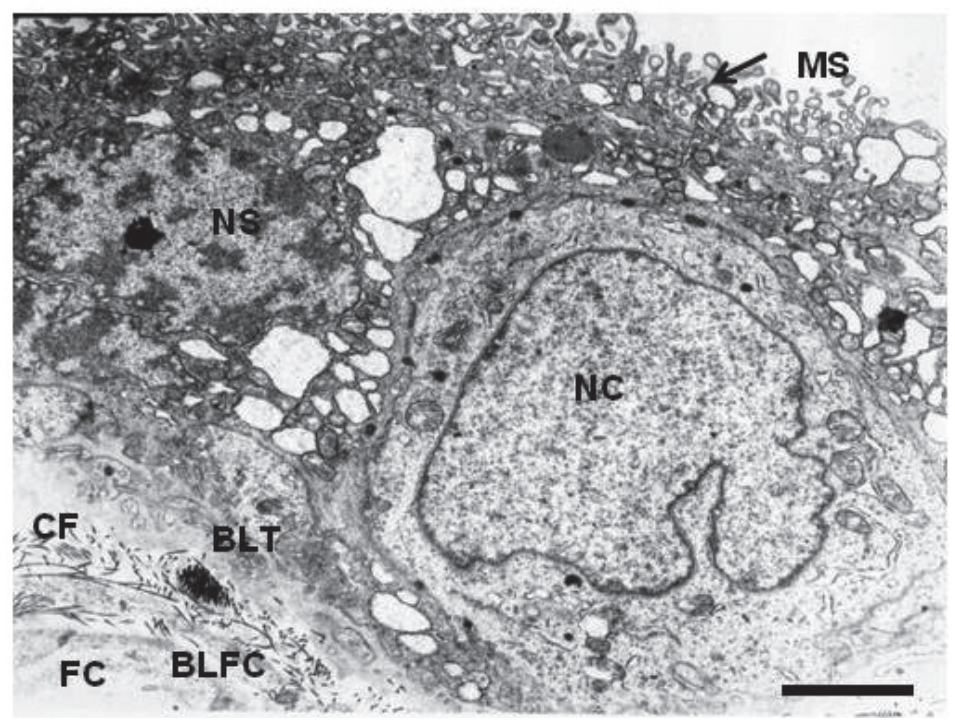

Figure 1: Placental maternofetal barrier: The maternofetal barrier is composed of syncytiotrophoblast (ST), cytotrophoblast (CT), fetal connective tissue of the villous stroma (VS), fetal capillary (FC) and basal lamina between Villous stroma and trophoblast (BLT) and around fetal endothelium (FCBL) (A-E). After week 20, the placenta undergoes adaptations that improve metabolic exchange, cytotrophoblastic cells diminish in number, the nuclei of syncytiotrophoblast cells group together forming nodes and the fetal capillaries come close to the trophoblast (C-D) and thus the placental membrane transforms into a thinner barrier. Microphotography of a placental membrane from a human term placenta is shown in E: Microvilli at the apical surface of the syncytium (arrow) toward the intervillous space (IS); nucleous of the cytotrophoblast (NC), nucleous of the syncyitum (NS), basal lamina of the trophoblast (BLT), collagen fiber of the fetal connective tissue (CL), fetal capillary (FC) and the basal lamina of the fetal capillary (BLFC), bar $2.86 \mu \mathrm{m}$. 
The restructured placental barrier possibly facilitates the invasion of diverse pathogens. Among these are the human immunodeficiency virus (HIV), the viruses that cause hepatitis B and C, varicella zoster, rubella, parvovirus B19 (Koi, et al 2001) and cytomegalovirus (Koi, et al 2001; Halwachs-Baumann, 2006), as well as mycoplasma (Dische et al 1979). In addition to T. cruzi, other congenital diseases caused by parasites have also been described, among which Plasmodium falciparum, the agent responsible for causing malaria, (Rogerson, et al.2007; Desai, et al 2007), schistosoma (Friedman, et al. 2007), Toxoplasma gondii (Biedermann, 1995; Correa, et al 2007) and Trypanosoma brucei (Rocha, et al 2004) are of importance.

During pregnancy, there is a predominating Th2 immune response that favors immunologic tolerance to the fetus (Raghupathy, 2001, Lin, et al 2005; Raghupathy and Kalinka 2008), but there is also increased susceptibility to certain autoimmune diseases and intracellular infections (Guilbert, et al 1993; Lin, et al 2005). Among these are the following: Acquired Immune Deficiency Syndrome (AIDS) (Derrien, et al 2005), infections associated with AIDS (Margono, et al 1994), malaria (Gamain, et al 2006) and toxoplasmosis (Biedermann,1995).

In non-infected newborns with Chagasic mothers, a strong activation of their innate immune response with an increased capacity to produce both proinflammatory (IL1- $\beta$, IL-6, TNF- $\alpha$ ) and anti-inflammatory (IL-10) cytokines by monocytes is observed. In addition, an increase in TNF- $\alpha$ receptors is also observed, when compared to infected newborns or healthy newborns with healthy mothers (Hermann, et al 2004; Carlier, 2005; Truyens, et al 2005; Hermann, et al 2006). Therefore, non-infected newborns with Chagasic mothers are able to mount a T CD8+ cellular immune response similar to that of an adult (Hermann, et al 2002). Similarly, transmitting mothers have a higher parasite load associated with higher parasitemia, diminished capacity to produce IFN- $\gamma$ by mononuclear blood cells, inability to produce IL-2 as a specific response to the parasite (Hermann, et al 2004; Carlier, 2005; Alonso-Vega, et al 2005), a greater capacity to produce IL-10 (anti-inflammatory cytokine) (Alonso-Vega, et al 2005), and low levels of circulating TNF (Garcia, et al 2008). On the contrary, non-transmitting Chagasic mothers show high monocyte activation levels (Carlier, 2005; Alonso-Vega, et al 2005; Hermann, et al 2006) and high levels of circulating TNF (Garcia, et al 2008).

There are only a few studies that describe the histopathological lesions of placentas from both transmitting and non-transmitting mothers infected with Chagas' disease. These analyses were carried out with routine histological techniques (haematoxilin-eosin) and the lesions were described as "chorionitis", "chorioamnionitis", and "umbilical chord edema" (Fernandez-Aguilar, et al 2005). Unfortunately, histochemical and immunohistochemical techniques were not applied in order to determine with greater certainty the presence of parasites and that of cellular and molecular alterations in the chorionic villi. Another study, classified inflammatory cells present in placentas infected with T. cruzi, describing a predomination of CD68+ macrophages, $\mathrm{T}$ lymphocytes (CD4+: CD8+ ratio between 0.04 and 0.38 ), some NK cells (natural killer), and almost no or null presence of B lymphocytes (Altemani, et al 2000). Predomination of mononuclear cells is characteristic of any chronic inflammatory response to an infectious agent (Kumar, et al 2005). The cytotoxic lymphocyte predomination could be explained by a response to an intracellular pathogen (Hermann, et al 2002). In that study, no difference was made between transmitting and nontransmitting mothers with Chagas' disease, nor was placental histopathology described in detail. Placentas from live newborn births and still births were separated. In placentas from stillbirths, extended areas of necrosis and abundant parasites were observed when compared to placentas from live births (Altemani, et al 2000).

\section{MECHANISMS OF T. CRUZI INFECTION AND INVASION}

Parasite invasion in cell cultures has been studied in some depth (Andrade, et al 2005). On the other hand, studies that analyze parasite invasion in tissues and organs are rare. $T$. cruzi penetration in host cells occurs through a complex multi-step process that includes both parasite and host cells. Parasite attachment to host cells is receptor mediated. T. cruzi possesses a series of surface molecules that interact in a differential manner with molecules from the host's cells and extracellular matrix (ECM) (Yoshida, 2006). T. cruzi cellular invasion induces calcium signals and activation of signal transduction pathways both in the parasite and the host (Yoshida, 2006; Yoshida 2008). The parasite's capacity to generate calcium signals in the host is related to its infectivity (Manque et al 2003, Yoshida 2008). The activation of signal transduction pathways that lead to the generation of calcium signals requires two peptidases (Burleigh and Woolsey 2002), a serine endopeptidase, oligopeptidase B (Burleigh and Andrews 1995), and a secreted lysosomal cystein protease, cruzipain (Scharfstein, et al 2000).

Signal transduction pathway activation in the host:

Phospholipase C (PLC) activation is one of the most important signal transduction pathways because it generates Inositol-3-phosphate (IP3), which leads to calcium liberation from intracellular deposits (Rodriguez, et al 1995; Yoshida 2006). This increase in calcium induces recruitment (Andrews, 2002) and fusion of lysosomes (Jaiswal, et al 2002) with the plasma membrane at the site of parasite invasion. This process is boosted by a concomitant rise in cyclic AMP (Rodriguez, et al 1999). Disorganization of the cytoskeleton is also produced by de-polymerization of actin filaments (Rodriguez, et al 1995; Woolsey and Burleigh 2004; Yoshida, 2006; Yoshida, 2008).

During cell invasion, phosphoinositol 3-kinases (PI 3Ks) are also activated; inhibition of these kinases blocks the parasite's internalization (Todorov, et al 2000; Yoshida, 2006). The regulatory sub-unit of PI-3K, p85, co-localizes with actin filaments at the sites of parasite entry into macrophages (Vieira, et al 2002).

In phagocytic cells, such as macrophages, a protein tyrosinekinase (PTK) has been associated with parasite cellular invasion due to that PTK inhibition lowers the rate of parasite endocytosis (Vieira, et al 1994; Woolsey and Burleigh 2004). When these cells are invaded, an accumulation of tyrosine phosphorylated residues have been observed, in domains rich in actin $F$ on the cell surface (Vieira, et al 2002). On the contrary, in non-phagocytic cells 
PTKs seem to be unnecessary. In these cells, parasite invasion induces phosphatases, since the inhibition of tyrosine-protein phosphatases significantly reduces the rate of infection (Zhong, et al 1998).

During parasite invasion, other proteinkinase B (PKB/ Akt) is activated and its inhibition also reduces the rate of infection (Wilkowsky et al 2001). Another signal transduction pathway that has been associated with the process of parasite invasion is protein kinase C (PKC) activation (Burleigh and Woolsey 2002); in macrophage culture, the presence of recombinant gp83, a parasite surface glycoprotein, activates PKC (Villalta, et al 1999; Yoshida, 2006). In macrophages, activation of signal transduction pathways that lead to stimulation of transcription factor NF$\mathrm{B}$, that participates in the regulation of the expression of a wide number of pro-inflammatory cytokine genes, has been described, which in turn could reduce the infection rate (Ropert, et al 2001; Burleigh and Woolsey 2002). On the contrary, in cardiac muscle cells NF-кB activation might facilitate parasite invasion (Machado, et al 2000; Nagajyothi et al 2006). In other cell types, such as smooth and skeletal muscle cells (Hall, et al 2000), as in fibroblasts (Vaena de Avalos, et al 2002), no NF- $\mathrm{B}$ activation is observed. In addition, in cardiac muscle NF- $\mathrm{B}$ activation and transcription factor AP-1 via MAPK ERK1/2 (mitogenactivated protein kinases, serine treonine kinases) could be partially responsible for changing hypertrophic to hyperplasic growth (Nagajyothi, et al 2006). MAPK ERK1/2 activation has also been observed in smooth muscle cells, endothelial cells (Mukherjee, et al 2004), and macrophages (Villalta, et al 1998). In cardiac muscle cells (Huang 2003) and cardiac vessel endothelium (Mukherjee, 2004) MAPK ERK1/2 activation induces an increase in cyclin D1 protein levels. In smooth muscle cells, cellular proliferation is induced by MAPK ERK1/2-cyclinD1 activation (Hassan, 2006). In PC12 cells, the parasite surface glycoprotein, transialidase, induces differentiation into a neuronal phenotype via MAPK ERK 1/2 (Villalta, et al 1998) and PKC (Villalta, et al 1999). In macrophages, during phagocytosis of the parasite, MAPK ERK1/2 (Villalta, et al 1998) and PKC (Villalta, et al 1999) are also activated. Parasite endocytosis in these cells is inhibited by specific inhibitors of these kinases. Therefore, activation of this pathway participates both in the internalization of the parasite into different cell types and in the induction of cell proliferation and differentiation.

\section{T. cruzi interaction with the host ECM:}

ECM is composed of different combinations of protein fibers (collagen and elastic fibers) and ground substance. Ground substance is a highly hydrophilic, viscous complex of anionic macromolecules (glycoaminoglycans and proteoglycans) and multiadhesive glycoproteins (laminin, fibronectin and others), that impair strength and rigidity of the matrix by binding to receptor proteins like integrins on the surface of cells and other matrix components. The ECM also forms basal laminas, structures found between epithelial and connective tissues. Besides its structural function, the ECM serves other important biological functions such as being a reservoir of hormones and growth factors (Junqueira and Carneiro 2005), and a cytokine and chemokine modulator during immune and inflammatory responses (Kumar, et al 2005). During tissue invasion by the parasite, interaction between $T$. cruzi and the ECM is fundamental. The parasite must cross the basal laminae located between different epithelia and adjacent connective tissue, and to mobilize itself within these tissues. Macrophages are found in connective tissues, where they participate in the inflammatory response and in the initiation of a more specific immune response (Junqueira and Carneiro 2005; Kumar et al 2005). On the other hand, macrophages are the first connective tissue cells that are invaded by $T$. cruzi (Burleigh and Woolsey 2002). During the inflammatory response cell-cell and cell-ECM interactions are established that are mediated by adhesion molecules and integrins (Marino, et al 2003). The parasite presents surface molecules, such as gp 85 (Merino, et al 2003) and gp83 (Nde, et al 2006) glycoproteins, with which it binds to ECM glycoproteins such as laminin (Giordano, et al 1999, Marino, et al 2003, Nde, et al 2006) and fibronectin (Marino, et al 2003), sulfated glycosamineglicans such as heparansulfate (Lima, et al 2002), and elements from the cytoskeleton (intermediate filaments) that are exposed in the plasma membrane, such as cytokeratine 18 (Magdesian, et al 2001, Marino, et al 2003). There is evidence that fibronectin promotes adhesion and endocytosis of the parasite in macrophages and fibroblasts (Wirth and Kierszenbaum 1984; Ouaissi, et al 1984; Marino, et al 2003). T. cruzi presents another surface molecule, penetrin, with which it binds to heparin, heparansulphate, and collagen thus promoting adhesion and internalization into fibroblasts (Ortega-Barria and Perreira 1991). The binding of gp83 to laminin promotes parasite internalization into macrophages (Nde et al 2006) and activates the MAK ERK1/2 signal transduction (Villalta, et al 1998) and PLC (Villalta, et al 1999) pathways.

The parasite secretes proteases (cruzipains) capable of degrading ECM components such as collagen type I, IV and fibronectin, exposing hidden epitopes (Santana, et al 1997; Scharfstein and Morrot 1999). Plasma fibronectin fragments have a growth factor type activity that induces differentiation of trypomastigotes into their intracellular replicative form, amastigotes (Ouaissi, et al 1992). In addition, heparansulphate increases cruzipain catalytic activity (Lima, et al 2002) which could favor the parasite advancement in tissues. Cruzipain could also have an antiapoptotic effect in cardiac muscle cells in culture since it activates different signal transduction pathways such as PI3K and MAPK ERK1/2 (Aoki, et al 2004) that, as described above, are activated during parasite internalization.

It has been proposed that ECM alterations produced by the parasite not only promote its motility in tissues and its entrance into cells, but also alter the presence of cytokines and chemokines, which in turn permits T. cruzi to modulate and escape both the inflammatory response and the immune response (Marino, et al 2003; Mendes-da-Silva, et al 2006). The use of RNA aptamers has been proposed in order to interfere with the interaction between parasites and laminin, fibronectin, trombospodin, or heparansulphate, thus inhibiting cellular invasion, objective that is partially reached in cell cultures (Ulrich, et al 2002).

The ECM is maintained by a variety of proteases and protease inhibitors, such as matrix metalloproteinases (MMPs) and their respective tissue inhibitors (Werb, et al 
1996; Gomez, et al 1997). MMPs comprise a vast class of zincdependent endopeptidases that are divided into families according to their substrates (Nagase and Woessner 1999). Increased levels of various MMPs (collagenases, stromelysins, and gelatinases) have been associated with inflammatory diseases of connective tissues (Opdenaker, et al 2001). Two of the most studied members of this family are MMP-2 (gelatinase A, $72 \mathrm{kDa}$ ) and MMP-9 (gelatinase B, 92 $\mathrm{kDa}$ ) (Corthorn, et al 2007). The actions of collagenases MMP-2 and MMP-9 are involved in regulation of the inflammatory response in several circumstances, including the direct cleavage of immune system proteins (Odenaker et al 2001). T. cruzi infection leads to increased levels of MMP-2 and MMP-9 and its inhibition reduce myocarditis and improve survival during the acute phase of infection (Gutierrez, et al 2008). On the contrary, ECM composition alterations, specifically an increase in the amount of collagen, have been described in the myocardium of patients with chronic chagasic myocarditis (Higushi, et al 1999). In T. cruzi infected mice, increased expression of laminin, fibronectin, collagen type III and IV, and a decrease in the amount of collagen type I are observed (Andrade, et al 1989). In three-dimensional myocardial cell cultures, a significant increase was reported of fibronectin, laminin and collagen type IV, 6 days post-infection with T. cruzi was (Garzoni, et al 2008). ECM alterations have also been described in other organs in T. cruzi infected mice. Thus, in increases of fibronectin and collagen type IV are observed in the thymus (Mendesda-Cruz, et al 2006); and increases laminin expression in the spleen and lymph nodes (Marino, et al 2003). It is probable that during the infection, the parasite initially promotes ECM degradation and, as a secondary response, the host produces an increase in ECM components.

Hence, parasite-ECM interactions induce intra and extracellular alterations. On the one hand, T. cruzi alters the ECM to the extent that the advancement of the parasite in tissues is facilitated, and allows the parasite to modulate the presence of growth factors, cytokines, and chemokines, that in turn permit the parasite to modify the inflammatory and immune responses. On the other hand, these parasite-ECM interactions induce signal transduction pathways that facilitate the entrance of $T$. cruzi into cells, a step that is crucial in the parasite's life cycle since it requires the intracellular medium in order to replicate in the host. Probably, during the early stages of invasion, the parasite promotes the degradation of the ECM, and thereafter, during the chronic stage of the disease an increase in the components of the ECM in infected tissues is produced, as one of the host's responses to intracellular amastigotes.

\section{PLACENTAL CHORIONIC VILLI INFECTION BY T. CRUZI:}

Induction of cellular alterations and interaction with the ECM during T. cruzi infection has been studied mainly in mammalian cell cultures. These cultures correspond to cell lines and not to primary cultures, nor do they correspond to human cells. Studies in human tissue are focused on the histopathologic examination of necropsies of Chagasic patients that do not provide information on mechanisms of invasion.

Nevertheless, there are some studies of parasite invasion on a cellular and tissue level. Thus, human placental tissue has been used as a possible study model for ex vivo parasitic tissue infection (Sartori, et al 2003 ; Lin, et al. 2004; Lujan, et al. 2004; Sartori, et al. 2005; Shippey, et al 2005; Mezzano, et 2005; Triquell, et al 2009, Duaso et al 2010). The possibility of having on a tissue culture for the study of parasitic invasion creates working conditions that are more like those in vivo.

Another advantage of this model is the possibility of using tissues of human origin. The placenta, which is expulsed from the mother's body during the placental stage of labor, does not serve any other purpose in the organism it originated from. It is easily obtained after labor, and its use does not harm the child's or mother's health. The use of placental tissue has been widespread for a long time in basic biomedical studies (Grimm, 1955; Seeho, et al 2008). Chorionic villi explant cultures have been used in studies on the effect of partial $\mathrm{O}_{2}$ pressures (especially hypoxia) in placental tissue related to pathologies such as pre-eclampsia (Benyo, et al 1997; James, et al 2006; Robinson, et al 2008; Seeho, et al 2008). In addition, this model has been used in cell differentiation studies (Fujiwara, 2007), effects of drugs (Gedeon and Koren 2006), viral cellular invasion (HalwachsBaumann 2006), and intracellular T. cruzi invasion (Sartori, et al 2003; Lin, et al. 2004; Lujan, et al. 2004; Sartori, et al. 2005; Mezzano, et al. 2005, Triquell, et al 2009, Duaso et al 2010). During ex vivo infection of human chorionic villi explants, T. cruzi induces syncytiotrophoblast destruction and detachment, selective disorganization of basal lamina and disorganization of collagen I in the connective tissue of villous stroma (Duaso et al 2010). Actin filaments in the syncytiotrophoblast became disorganizated (Sartori et al 2003), placental alkaline phosphatase is activated (Sartori, et al. 2005; Mezzano, et al 2005) and expression of the receptor for epidermic growth factor is increased (Lin, et al 2004).

Other studies have described the trypanocidal effect of supernatants from culture media in which chorionic villi were incubated (Lujan, et al 2004, Triquell, et al 2009). These trypanocidal effects could account for local placental antiparasitic defense mechanisms, such as trypanocidal "heat sensitive factors" (Lujan, et al. 2004), but unfortunately these factors have not been identified. The possible antiparasitic effect of local factors in the human placenta may explain the low rate $(1-21 \%)$ of congenital transmission and represents an important problem to be studied. During congenital transmission, maternal blood trypomastigotes must cross the placental barrier. We propose that the maternal blood tripomastigotes in the intervillous space infects syncytiotrophoblast, cytotrophoblast and fetal placental connective tissue of the villous stroma invading the different types of cells that constitutes these tissues. In the interior of the cells the trypomastigotes differentiate into amastigotes, proliferate and after a certain number of replications the amastigotes differentiate again into trypomastigotes, which could invades the fetal capillary and in this way reach the fetus (Fig. 2). This invasion of the placental tissue may be facilitated after week 20 of pregnancy due to the physiological metabolic adaptation of the placenta (Fig 1). The use of placental tissue explants in order to study both the mechanisms of infectivity and invasion will advance our knowledge of the physiopathology of congenital Chagas' disease. In particular, the study of the parasite-ECM interactions at structural and ultrastructural levels and their relationships with the parasite's internalization into different 


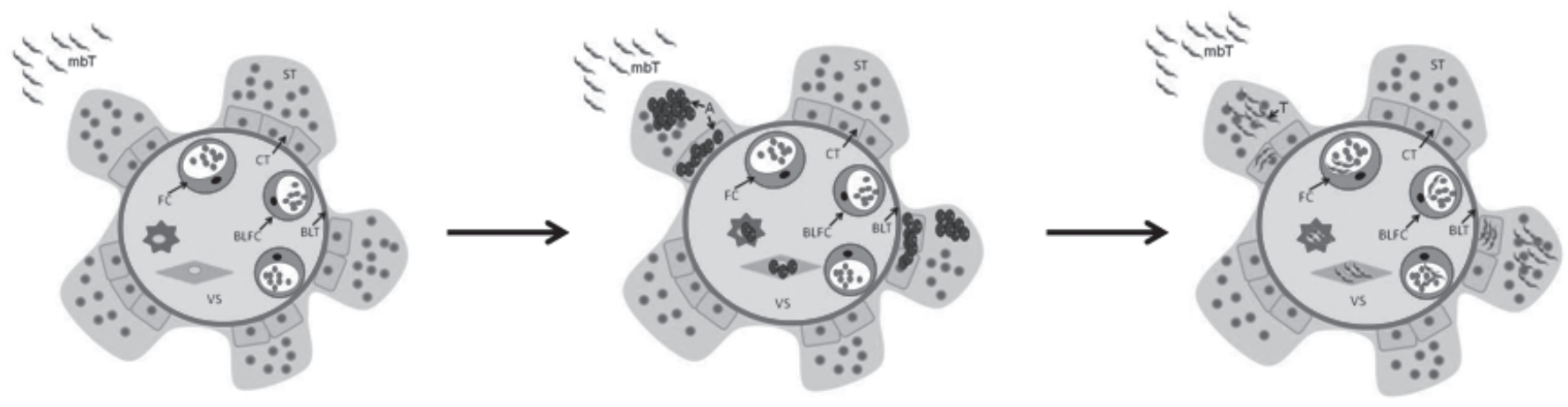

Figure 2: Probable mechanism of congenital transmission of $\boldsymbol{T}$. cruzi: During congenital transmission maternal blood tripomastigotes (mbT) must cross the placental barrier. We propose that the maternal blood tripomastigotes in the placental intervillous space infects syncytiotrophoblast (ST), cytotrophoblast (CT) and Villous stroma (VS) invading the different types of cells that constitutes these tissues. In the interior of these cells and in the syncytiotrophoblast the trypomastigotes differentiate into amastigotes (A), proliferate and after a certain number of replication the amastigotes differentiates again into trypomastigotes ( $\mathrm{T}$ ) which could invade the fetal capillary and in this way infect the fetus.

human placental cells is of particular importance. Additionally, the possibility to study possible antiparasitic mechanisms in this tissue may allow development of new therapeutic and preventive strategies. Last but not least, this model may be useful to study the effect and toxicity of antichagasic drugs.

\section{ACKNOWLEDGMENTS}

This work was supported by a grant from FONDECYT to UK 11080166 and 1090124 to NG and Bicentenario Anillo ACT29 and ACT 112.

\section{REFERENCES}

ALONSO-VEGA C, HERMANN E, TRUYENS C, RODRÍGUEZ $\mathrm{P}$, TORRICO MC, TORRICO F, CARLIER Y. (2005) Immunological status of mothers infected with Trypanosoma cruzi. Rev Soc Bras Med Trop. 38 Suppl 2: 101-4.

ALTEMANI AM, BITTENCOURT AL, LANA AM (2000) Immunohistochemical characterization of the inflammatory infiltrate in placental chagas'disease: A cualitative and quantitative analysis. Am J. Trop. Med. Hyg. 62(2): 319-324

AMINO R, MARTINS RM, PROCOPIO J, HIRATA IY, JULIANO M. (2002) Trialysin, a novel pore-forming protein from saliva of hematophagous insects activated by limited proteolysis. J Biol Chem 277: 6207-6213.

ANDRADE LO, ANDREWS NW. (2005) The Trypanosoma cruzi-host-cell interplay: location, invasion, retention. Nat Rev Microbiol. 3(10): 81923.

ANDRADE SG, GRIMAUD JA, STOCKER-GUERRET S. (1989) Sequential changes of the connective matrix components of the myocardium (fibronectin and laminin) and evolution of cardiac fibrosis in mice infected with Trypanosoma cruzi. Am J Trop Med Hyg. 40(3): 252-60.

ANDRADE SG. The influence of the strain of Trypanosoma cruzi in placental infections in mice. (1982) Trans R Soc Trop Med Hyg 76: 123-8

ANDREWS NW. (2002) Lysosomes and the plasma membrane: trypanosomes reveal a secret relationship. J Cell Biol. 158(3): 389-94.

AOKI MP, GUINAZU NL, PELLEGRINI AV, GOTOH T, MASIH DT, GEA S. (2004) Cruzipain, a major Trypanosoma cruzi antigen, promotes arginase-2 expression and survival of neonatal mouse cardiomyocytes. Am J Physiol Cell Physiol 286(2): C206-12.

AUFDERHEIDE AC, SALO $\mathrm{W}$, MADDEN M, STREITZ J, BUIKSTRA J, GUHL F, ARRIAZA B, RENIER C, WITTMERS LE JR, FORNACIARI G, ALLISON M. (2004) A 9,000-year record of Chagas' disease. Proc Natl Acad Sci U S A. 101(7): 2034-9.

BENYO DF, MILES TM, CONRAD KP. (1997) Hypoxia stimulates cytokine production by villous explants from the human placenta. J Clin Endocrinol Metab. 82(5): 1582-8.

BERNISCHKE K, KAUFMANN P, BAERGEN R (2006) Pathology of the Human Placenta. Fifth Edition. Springer Science+Business Media Inc. New York

BIEDERMANN K, FLEPP M, FIERZ W, JOLLER-JEMELKA H, KLEIHUES P. (1995) Pregnancy, immunosuppression and reactivation of latent toxoplasmosis. J Perinat Med. 23(3): 191-203.

BITTENCOURT AL. (1976) Congenital Chagas' disease. Am J Dis Child 130: $97-103$

BLANCO SB, SEGURA EL, CURA EN, CHUIT R, TULIA`N L, FLORES (2000) Congenital transmission of Trypanosoma cruzi: an operational outline for detecting and treating infected infants in northwestern Argentina. Trop Med Int Health 5: 293-301.

BOSCO C, BUFFET C, BELLO MA, RODRIGO R, GUTIERREZ M GARCIA G. (2007) Placentation in the degu (Octodon degus): analogies with extrasubplacental trophoblast and human extravillous trophoblast. Comp Biochem Physiol A Mol Integr Physiol. 146(4): $475-85$.

BURGOS JM, ALTCHEH J, BISIO M, DUFFY T, VALADARES HM, SEIDENSTEIN ME, PICCINALI R, FREITAS JM, LEVIN MJ, MACCHI L, MACEDO AM, FREILIJ H, SCHIJMAN AG. (2007) Direct molecular profiling of minicircle signatures and lineages of Trypanosoma cruzi bloodstream populations causing congenital Chagas disease. Int J Parasitol. 37(12): 1319-27.

BURLEIGH BA, ANDREWS NW. (1995) The mechanisms of Trypanosoma cruzi invasion of mammalian cells. Annu Rev Microbiol.49: 175-200.

BURLEIGH BA, WOOLSEY AM. (2002) Cell signalling and Trypanosoma cruzi invasion. Cell Microbiol. 4(11): 701-11.

CARLIER Y. (2005) Factors and mechanisms involved in the transmission and development of congenital infection with Trypanosoma cruzi Rev Soc Bras Med Trop. 38 Suppl 2: 105-7.

CASTRO JA, DE MECCA MM, BARTEL LC. (2006) Toxic side effects of drugs used to treat Chagas' disease (American trypanosomiasis). Hum Exp Toxicol. 25(8): 471-9.

CEROUEIRA GC, BARTHOLOMEU DC, DAROCHA WD, HOU L, FREITAS-SILVA DM, MACHADO CR, EL-SAYED NM, TEIXEIRA SM. (2008) Sequence diversity and evolution of multigene families in Trypanosoma cruzi. Mol Biochem Parasitol. 157(1): 65-72.

CORREA D, CANEDO-SOLARES I, ORTIZ-ALEGRIA LB, CABALLEROORTEGA H, RICO-TORRES CP. (2007) Congenital and acquired toxoplasmosis: diversity and role of antibodies in different compartments of the host. Parasite Immunol. 29(12): 651-60.

CORTHORN J, REY S, CHACON C, VALDES G. (2007) Spatio-temporal expression of MMP-2, MMP-9 and tissue kallikrein in uteroplacental units of the pregnant guinea-pig (Cavia porcellus). Reprod Biol Endocrinol. Jul 2;5: 27

COURA JR (2007) Chagas disease: what is known and what is needed: a background article. Mem Inst Oswaldo Cruz. Oct 30;102 Suppl 1: 11322.

COURA JR. (2006) Transmission of chagasic infection by oral route in the 
natural history of Chagas disease Rev Soc Bras Med Trop.;39 Suppl 3: 113-7.

CROSS JC. (2006) Placental function in development and disease. Reprod Fertil Dev.18(1-2): 71-6.

CHAGAS, C. (1909). Nova tripanosomiase humana. Estudios sobre a morfologia e o ciclo evolutivo do Schizotrypanum cruzi n.gen, n.sp., agente etiologico do nova entidae mórbida do homen. Mem. Inst. Oswaldo Cruz 1: 159-218.

CHUENKOVA MV, PEREIRA MA. (2001) The T. cruzi trans-sialidase induces PC12 cell differentiation via MAPK/ERK pathway. Neuroreport. 12(17): 3715-8.

DE SOUZA W. (2002) From the cell biology to the development of new chemotherapeutic approaches against trypanosomatids: dreams and reality. Kinetoplastid Biol Dis. May 31;1(1): 3

DERRIEN M, FAYE A, DOLCINI G, CHAOUAT G, BARRE-SINOUSSI F, MENU E. (2005) Impact of the placental cytokine-chemokine balance on regulation of cell-cell contact-induced human immunodeficiency virus type 1 translocation across a trophoblastic barrier in vitro. J Virol. 79(19): 12304-10.

DESAI M, TER KUILE FO, NOSTEN F, MCGREADY R, ASAMOA K, BRABIN B, NEWMAN RD. (2007) Epidemiology and burden of malaria in pregnancy. Lancet Infect Dis. 7(2): 93-104.

DI NOIA JM, BUSCAGLIA CA, DE MARCHI CR, ALMEIDA IC, FRASCH AC. (2002) A Trypanosoma cruzi small surface molecule provides the first immunological evidence that Chagas' disease is due to a single parasite lineage. J Exp Med.195(4): 401-13.

DISCHE MR, QUINN PA, CZEGLEDY-NAGY E, STURGESS JM. (1979) Genital mycoplasma infection. Intrauterine infection: pathologic study of the fetus and placenta. Am J Clin Pathol. 72(2): 167-74.

DUASO J, ROJO G, CABRERA G, GALANTI N, BOSCO C, MAYA JD, MORELLO A AND KEMMERLING U. (2010) "Trypanosoma cruzi induces tissue disorganization and destruction of chorionic villi in an ex vivo infection model of human placenta". Placenta 31 (8) 705-11.

FERNANDEZ-AGUILAR S, LAMBOT MA, TORRICO F, ALONSO-VEGA C, CÓRDOBA M, SUÁREZ E, NOEL JC, CARLIER Y. (2005) Placental lesions in human Trypanosoma cruzi infection Rev Soc Bras Med Trop. 38 Suppl 2: 84-6.

FRAGATA FILHO AA, CORREIA EDE B, BORGES FILHO R, VASCONCELOS M DE O, JANCZUK D, MARTINS CS. (2008) sequence of unusual Chagas infection transmissions in the same family: mother by blood transfusion and child congenitally, with a treatment-resistant strain of Trypanosoma cruzi. Rev Soc Bras Med Trop. 41(1): 73-5

FREITAS JM, LAGES-SILVA E, CREMA E, PENA SD, MACEDO AM. (2005) Real time PCR strategy for the identification of major lineages of Trypanosoma cruzi directly in chronically infected human tissues. Int J Parasitol. 35(4): 411-7.

FRIEDMAN JF, MITAL P, KANZARIA HK, OLDS GR, KURTIS JD. (2007) Schistosomiasis and pregnancy. Trends Parasitol. 23(4): 159-64.

FUIIWARA H. (2007) Membrane-bound peptidases regulate human extravillous trophoblast invasion. Placenta. 28 Suppl A: S70-5.

GAMAIN B, SMITH JD, VIEBIG NK, GYSIN J, SCHERF A. (2007) Pregnancyassociated malaria: parasite binding, natural immunity and vaccine development. Int J Parasitol. 37(3-4): 273-83.

GARCIA MM, DE RISSIO AM, VILLALONGA X, MENGONI E, CARDONI RL. (2008) Soluble tumor necrosis factor (TNF) Receptors (sTNF-R1 and -R2) in pregnant women chronically infected with Trypanosoma cruzi and their children. Am J Trop Med Hyg. 78(3): 499503.

GARZONI LR, ADESSE D, SOARES MJ, ROSSI MI, BOROJEVIC R, MEIRELLES MD. (2008) Fibrosis and Hypertrophy Induced by Trypanosoma cruzi in a Three- Dimensional Cardiomyocyte-Culture System. J Infect Dis. 197(6): 906-915.

GEDEON C, KOREN G. (2005) Designing pregnancy centered medications: drugs which do not cross the human placenta. Placenta. 27(8): 861-8.

GIORDANO R, FOUTS DL, TEWARI D, COLLI W, MANNING JE AND ALVES MJM. (1999). Cloning of a surface membrane glycoprotein specific for the infective form of Trypanosoma cruzi having adhesive properties to laminin. J Biol Chem 274: 3461-3468.

GRIMM H. (1955) An observation on the growth-promoting and growthinhibiting substance of the placenta. Z Arztl Fortbild (Jena). 49(1516): 531-5.

GOMEZ DE, ALONSO DF, YOSHIJI H, THORGEIRSSON UP. Tissue inhibitors of metalloproteinases: structure, regulation and biological functions. Eur J Cell Biol 1997;74: 111-22.
GUILBERT L, ROBERTSON SA, WEGMANN TG. (1993) The trophoblast as an integral component of a macrophage-cytokine network. Immunol Cell Biol. 71 (Pt 1): 49-57.

GUTIERREZ FR, LALU MM, MARIANO FS, MILANEZI CM, CENA J, GERLACH RF, SANTOS JE, TORRES-DUENAS D, CUNHA FQ, SCHULZ R, SILVA JS. (2008) Increased Activities of Cardiac Matrix Metalloproteinases Matrix Metalloproteinase (MMP)-2 and MMP-9 Are Associated with Mortality during the Acute Phase of Experimental Trypanosoma cruzi Infection. J Infect Dis. May 15;197 (10): 1468-1476.

HALWACHS-BAUMANN G. (2006) The congenital cytomegalovirus infection: virus-host interaction for defense and transmission. Curr Pharm Biotechnol. 7(4): 303-12.

HALL BS, TAM W, SEN R, PEREIRA ME. (2000) Cell-specific activation of nuclear factor-kappaB by the parasite Trypanosoma cruzi promotes resistance to intracellular infection. Mol Biol Cell. 11(1): 153-60.

HERMANN E, ALONSO-VEGA C, BERTHE A, TRUYENS C, FLORES A, CÓRDOVA M, MORETTA L, TORRICO F, BRAUD V, CARLIER Y. (2006) Human congenital infection with Trypanosoma cruzi induces phenotypic and functional modifications of cord blood NK cells. Pediatr Res. 60(1): 38-43.

HERMANN E, TRUYENS C, ALONSO-VEGA C, EVEN J, RODRIGUEZ P, BERTHE A, GONZALEZ-MERINO E, TORRICO F, CARLIER $Y$. (2002) Human fetuses are able to mount an adultlike CD8 T-cell response. Blood. 100(6): 2153-8.

HERMANN E, TRUYENS C, ALONSO-VEGA C, RODRÍGUEZ P, BERTHE A, TORRICO F, CARLIER Y. (2004) Congenital transmission of Trypanosoma cruzi is associated with maternal enhanced parasitemia and decreased production of interferongamma in response to parasite antigens. J Infect Dis. 189(7): 1274-81.

HIGUCHI ML, FUKASAWA S, DE BRITO T, PARZIANELLO LC, BELLOTTI G, RAMIRES JA. (1999) Different microcirculatory and interstitial matrix patterns in idiopathic dilated cardiomyopathy and Chagas' disease: a three dimensional confocal microscopy study. Heart. 82(3): 279-85.

JAISWAL JK, ANDREWS NW, SIMON SM. (2002) Membrane proximal lysosomes are the major vesicles responsible for calcium-dependent exocytosis in nonsecretory cells. J Cell Biol. 159(4): 625-35.

JAMES JL, STONE PR, CHAMLEY LW. (2006) The effects of oxygen concentration and gestational age on extravillous trophoblast outgrowth in a human first trimester villous explant model. Hum Reprod. 21(10): 2699-705. Epub 2006 Jun 28.

JUNQUEIRA LC AND CARNEIRO J. (2005) Basic Histology: Text and Atlas 11 edition McGraw-Hill Company

KIRCHHOFF LV. (1993) American trypanosomiasis (Chagas' disease) a tropical disease now in the United States. N Engl J Med 329: 639-44.

KIRCHHOFF, L.V. (1999) Chagas disease (American Trypanosomiasis): a tropical disease now emerging in the United States. In: Emerging Infections 3 (Scheld, W.M. et al., eds), pp. 111-134, ASM Press

KOI H, ZHANG J, PARRY S. (2001) The Mechanisms of Placental Viral Infection Ann N Y Acad Sci. 943: 148-56.

KUMAR V, ABBAS AK, FAUSTO N. (2005) Robbins and Cotran Pathologic Basis of Disease. 7th ed. St. Louis, Mo: WB Saunders

LESCURE FX, CANESTRI A, MELLIEZ H, JAUREGUIBERRY S, DEVELOUX M, DORENT R, GUIARD-SCHMID JB, BONNARD P, AJANA F, ROLLA V, CARLIER Y, GAY F, ELGHOUZZI MH, DANIS M, PIALOUX G. (2008) Chagas Disease, France. Emerg Infect Dis. 14(4): 644-646.

LIMA AP, ALMEIDA PC, TERSARIOL IL, SCHMITZ V, SCHMAIER AH, JULIANO L, HIRATA IY, MULLER-ESTERL W, CHAGAS JR, SCHARFSTEIN J. (2002) Heparan sulfate modulates kinin release by Trypanosoma cruzi through the activity of cruzipain. J Biol Chem. 277(8): 5875-81

LIN S, SARTORI MJ, MEZZANO L, DE FABRO SP. (2004) Epidermal growth factor (EGF) in the human placental infection with Trypanosoma cruzi. Placenta. 25(4): 283-6.

LIN S, SARTORI MJ, MEZZANO L, DE FABRO SP. (2005) Placental alkaline phosphatase (PLAP) enzyme activity and binding to IgG in Chagas' disease. Placenta. 26(10): 789-95.

LUJAN CD, TRIQUELL MF, SEMBAJ A, GUERRERO CE, FRETES RE. (2004) Trypanosoma cruzi: productive infection is not allowed by chorionic villous explant from normal human placenta in vitro. Exp Parasitol. 108(3-4): 176-81.

MACHADO FS, MARTINS GA, ALIBERTI JC, MESTRINER FL, CUNHA FQ, SILVA JS. (2000) Trypanosoma cruzi-infected cardiomyocytes 
produce chemokines and cytokines that trigger potent nitric oxidedependent trypanocidal activity. Circulation. 102(24): 3003-8.

MAGALHAES JB, ANDRADE SG, SHERLOCK I. (1996) Trypanosoma cruzi strains: behavior after passage into authoctonous or foreign species of traitomine (biological and biochemical patterns). Rev Inst Med Trop Sao Paulo. 38(1): 23-8.

MAGDESIAN MH, GIORDANO R, ULRICH H, JULIANO MA, JULIANO L, SCHUMACHER RI, COLLI W, ALVES MJ. (2001) Infection by Trypanosoma cruzi. Identification of a parasite ligand and its host cell receptor. J Biol Chem. 276(22): 19382-9.

MANOEL-CAETANO FDA S, SILVA AE. (2007) Implications of genetic variability of Trypanosoma cruzi for the pathogenesis of Chagas disease. Cad Saude Publica. 23(10): 2263-74.

MANQUE PM, NEIRA I, ATAYDE VD, CORDERO E, FERREIRA AT, DA SILVEIRA JF, RAMIREZ M, YOSHIDA N. (2003) Cell adhesion and Ca2+ signaling activity in stably transfected Trypanosoma cruzi epimastigotes expressing the metacyclic stagespecific surface molecule gp82. Infect Immun. 71(3): 1561-5.

MARGONO F, MROUEH J, GARELY A, WHITE D, DUERR A, MINKOFF HL. (1994) Resurgence of active tuberculosis among pregnant women. Obstet Gynecol.83(6): 911-4.

MARINO AP, SILVA AA, PINHO RT, LANNES-VIEIRA J. (2003) Trypanosoma cruzi infection: a continuous invader-host cell cross talk with participation of extracellular matrix and adhesion and chemoattractant molecules. Braz J Med Biol Res. 36(8): 1121-33.

MAYA JD, CASSELS BK, ITURRIAGA-VASQUEZ P, FERREIRA J, FAUNDEZ M, GALANTI N, FERREIRA A, MORELLO A. Mode of action of natural and synthetic drugs against Trypanosoma cruzi and their interaction with the mammalian host. Comp Biochem Physiol A Mol Integr Physiol. 2007 Apr;146(4): 601-20.

MENDES-DA-CRUZ DA, SILVA JS, COTTA-DE-ALMEIDA V, SAVINO W. (2006) Altered thymocyte migration during experimental acute Trypanosoma cruzi infection: combined role of fibronectin and the chemokines CXCL12 and CCL4. Eur J Immunol. 36(6): 1486-93.

MEZZANO L, SARTORI MJ, LIN S, REPOSSI G, DE FABRO SP. (2005) Placental alkaline phosphatase (PLAP) study in diabetic human placental villi infected with Trypanosoma cruzi. Placenta. 26(1): 85-92.

MOORE KL AND PERSEAUD TVN. (2004) The Developing Human, Clinically Oriented Embryology $7^{\circ}$ edition Elsevier

MORELLO, A., LETELIER, M.E., ALDUNATE, J. AND REPETTO,Y. (1987). Enfermedad de Chagas, biotransformacion de xenobioticos por el Trypanosoma cruzi. In: Estudios en honor de Gustavo Hoecker. Auch 14: 33-48.

MUKHERJEE S, HUANG H, PETKOVA SB, ALBANESE C, PESTELL RG, BRAUNSTEIN VL, CHRIST GJ, WITTNER M, LISANTI MP, BERMAN JW, WEISS LM, TANOWITZ HB. (2004) Trypanosoma cruzi infection activates extracellular signalregulated kinase in cultured endothelial and smooth muscle cells. Infect Immun. 72(9): 5274-82.

NAGAJYOTHI F, DESRUISSEAUX M, BOUZAHZAH B, WEISS LM, ANDRADE DDOS S, FACTOR SM, SCHERER PE, ALBANESE C, LISANTI MP, TANOWITZ HB. (2006) Cyclin and caveolin expression in an acute model of murine Chagasic myocarditis. Cell Cycle 5(1): 107-12.

NAGASE H, WOESSNER JF JR. Matrix metalloproteinases. J Biol Chem 1999; 274: 21491- 4.

NDE PN, SIMMONS KJ, KLESHCHENKO YY, PRATAP S, LIMA MF, VILLALTA F. (2006) Silencing of the laminin gamma-1 gene blocks Trypanosoma cruzi infection. Infect Immun. 74(3): 1643-8.

NISIDA IVV, AMATO-NETO V, BRAZ LMA, DUARTE MIS, UMEZAWA ES. (1999) A survey of congenital Chagas' disease, carried out at three health institutions in Sao Paolo City, Brazil. Rev Inst Med Trop Sao Paulo 41: 305-11

ORTEGA-BARRIA E, PEREIRA ME. (1991) A novel T. cruzi heparinbinding protein promotes fibroblast adhesion and penetration of engineered bacteria and trypanosomes into mammalian cells. Cell. 67(2): 411-21.

OUAISSI MA, CORNETTE J AND CAPRON A. (1986) Identification and isolation of Trypanosoma cruzi trypomastigote cell surface protein with properties expected of a fibronectin receptor. Mol Biochem Parasitol 19: 201-211.

OPDENAKKER G, VAN DEN STEEN PE, DUBOIS B (2001) Gelatinase B functions as regulator and effector in leukocyte biology. J Leukoc Biol; 69: 851-9.

OUAISSI MA, CORNETTE J, CAPRON A. (1985) Trypanosoma cruzi: modulation of parasite-cell interaction by plasma fibronectin. Eur J Immunol. 15(11): 1096-101.
PRATA A. (2001) Clinical and epidemiological aspects of Chagas disease Lancet Infect Dis. Sep;1(2): 92-100.

RAGHUPATHY R, KALINKA J. (2008) Cytokine imbalance in pregnancy complications and its modulation. Front Biosci. 1;13: 985-94.

RAGHUPATHY R. (2001) Pregnancy: success and failure within the Th1 Th2/Th3 paradigm. Semin Immunol. 13(4): 219-27.

ROBINSON NJ, WAREING M, HUDSON NK, BLANKLEY RT, BAKER PN, APLIN JD, CROCKER IP. (2008) Oxygen and the liberation of placental factors responsible for vascular compromise. Lab Invest. 88(3): 293-305.

ROCHA G, MARTINS A, GAMA G, BRANDAO F, ATOUGUIA J. (2004) Possible cases of sexual and congenital transmission of sleeping sickness. Lancet. 17;363(9404): 247.

RODRÍGUEZ A, MARTÍNEZ I, CHUNG A, BERLOT CH, ANDREWS NW. (1999) cAMP regulates Ca2+-dependent exocytosis of lysosomes and lysosome-mediated cell invasion by trypanosomes. J Biol Chem. 274(24): 16754-9.

RODRIGUEZ A, RIOULT MG, ORA A, ANDREWS NW. (1995) A trypanosome-soluble factor induces IP3 formation, intracellular Ca2+ mobilization and microfilament rearrangement in host cells. J Cell Biol. 129(5): 1263-73.

ROGERSON SJ, HVIID L, DUFFY PE, LEKE RF, TAYLOR DW. (2007) Malaria in pregnancy: pathogenesis and immunity. Lancet Infect Dis 7(2): 105-17.

ROPERT C, ALMEIDA IC, CLOSEL M, TRAVASSOS LR, FERGUSON MA, COHEN P, GAZZINELLI RT. (2001) Requirement of mitogenactivated protein kinases and I kappa B phosphorylation for induction of proinflammatory cytokines synthesis by macrophages indicates functional similarity of receptors triggered by glycosylphosphatidylinositol anchors from parasitic protozoa and bacterial lipopolysaccharide. J Immunol. 166(5): 3423-31.

SALAS C, TAPIA RA, CIUDAD K, ARMSTRONG V, ORELLANA M, KEMMERLING U, FERREIRA J, MAYA JD, MORELLO A. (2008) Trypanosoma cruzi: activities of lapachol and alpha- and betalapachone derivatives against epimastigote and trypomastigote forms. Bioorg Med Chem. 16(2): 668-74.

SANTANA JM, GRELLIER P, SCHREVEL J, TEIXEIRA AR. (1997) A Trypanosoma cruzi-secreted $80 \mathrm{kDa}$ proteinase with specificity for human collagen types I and IV. Biochem J. 325 (Pt 1): 129-37.

SARTORI MJ, MEZZANO L, LIN S, REPOSSI G, FABRO SP. (2005) Cellular components and placental alkaline phosphatase in Trypanosoma cruzi infection Rev Soc Bras Med Trop. 38 Suppl 2: 87-91.

SARTORI MJ, PONS P, MEZZANO L, LIN S, DE FABRO SP. (2003) Trypanosoma cruzi infection induces microfilament depletion in human placenta syncytiotrophoblast. Placenta. 24(7): 767-71.

SCHARFSTEIN J, MORROT A. (1999) A role for extracellular amastigotes in the immunopathology of Chagas disease. Mem Inst Oswaldo Cruz. 94 Suppl 1: 51-63.

SCHARFSTEIN J, SCHMITZ V, MORANDI V, CAPELLA MM, LIMA AP, MORROT A, JULIANO L, MULLER-ESTERL W. (2000) Host cell invasion by Trypanosoma cruzi is potentiated by activation of bradykinin B(2) receptors. J Exp Med. 192(9): 1289-300.

SCHMUNIS GA. (2007) Epidemiology of Chagas disease in non-endemic countries: the role of international migration. Mem Inst Oswaldo Cruz. 30;102 Suppl 1: 75-85.

SEEHO SK, PARK JH, ROWE J, MORRIS JM, GALLERY ED. (2008) Villous explants culture using early gestation tissue from ongoing pregnancies with known normal outcomes: the effect of oxygen on trophoblast outgrowth and migration. Hum Reprod. 23(5): 1170-9.

SHIPPEY SH III, ZAHN CM, CISAR MM, WU TJ, SATIN AJ. (2005) Use of the placental perfusion model to evaluate transplacental passage of Trypanosoma cruzi. Am J Obstet Gynecol. 192(2): 586-91.

SOARES MB, PONTES-DE-CARVALHO L AND RIBEIRO-DOS-SANTOS $R$ (2001) The pathogenesis of Chagas' disease: when autoimmune and parasite-specific immune responses meet. An Acad Bras Cienc 73: 547559.

TDR PUBLICATIONS, REPORTS AND INFORMATIONAL MATERIAL: Reporte sobre la enfermedad de Chagas Grupo de trabajo cientifico 17-20 de abril de (2005) Actualizado en julio de 2007 Buenos Aires, Argentina http: //www.who.int/tdr/publications/publications/ swg_chagas.htm

TRIQUELL MF, DÍAZ-LUJAN C, FREILIJ H, PAGLINI P, FRETES RE. Placental infection by two subpopulations of Trypanosoma cruzi is conditioned by differential survival of the parasite in a deleterious placental medium and not by tissue reproduction. Trans R Soc Trop Med Hyg (2009), doi: 10.1016/j.trstmh.2009.03.004 
TODOROV AG, EINICKER-LAMAS M, DE CASTRO SL, OLIVEIRA MM, GUILHERME A. (2000) Activation of host cell phosphatidylinositol 3-kinases by Trypanosoma cruzi infection. J Biol Chem. 275(41): 32182-6.

TORRICO F, CASTRO M, SOLANO M, RODRÍGUEZ P, TORRICO MC, TRUYENS C, CARLIER Y. (2005) Effects of maternal infection with Trypanosoma cruzi in pregnancy development and in the newborn infant Rev Soc Bras Med Trop.38 Suppl 2: 73-6.

TORRICO F, VEGA CA, SUAREZ E, TELLEZ T, BRUTUS L, RODRÍGUEZ P, TORRICO MC, SCHNEIDER D, TRUYENS C, CARLIER Y. (2006) Are maternal reinfections with Trypanosoma cruzi associated with higher morbidity and mortality of congenital Chagas disease? Trop Med Int Health. 11(5): 628-35.

TRUYENS C, HERMANN E, ALONSO-VEGA C, RODRÍGUEZ P, VEKEMANS J, TORRICO F, CARLIER Y. (2005) Immune responses of non-infected neonates of mothers infected with Trypanosoma cruzi Rev Soc Bras Med Trop. 38 Suppl 2: 96-100.

ULRICH H, MAGDESIAN MH, ALVES MJ, COLLI W. (2002) In vitro selection of RNA aptamers that bind to cell adhesion receptors of Trypanosoma cruzi and inhibit cell invasion. J Biol Chem. 277(23): 20756-62.

VAENA DE ÁVALOS S, BLADER IJ, FISHER M, BOOTHROYD JC, BURLEIGH BA. (2002) Immediate/early response to Trypanosoma cruzi infection involves minimal modulation of host cell transcription. J Biol Chem. 277(1): 639-44.

VIEIRA M, DUTRA JM, CARVALHO TM, CUNHA-ESILVA NL, SOUTOPADRON T AND SOUZA W. (2002) Cellular signaling during the macrophage invasion by Trypanosoma cruzi. Histochem Cell Biol 118: 491-500.

VIEIRA MC, DE CARVALHO TU, DE SOUZA W. (1994) Effect of protein kinase inhibitors on the invasion process of macrophages by Trypanosoma cruzi. Biochem Biophys Res Commun. 203(2): 967-71.

VILLALTA F, ZHANG Y, BIBB KE, BURNS JM JR, LIMA MF. (1998) Signal transduction in human macrophages by gp 83 ligand of Trypanosoma cruzi: trypomastigote gp83 ligand up-regulates trypanosome entry through the MAP kinase pathway. Biochem Biophys Res Commun. 249(1): 247-52.

VILLALTA F, ZHANG Y, BIBB KE, PRATAP S, BURNS JM JR, LIMA MF. (1999) Signal transduction in human macrophages by gp 83 ligand of Trypanosoma cruzi: trypomastigote gp83 ligand up-regulates trypanosome entry through protein kinase $\mathrm{C}$ activation. Mol Cell Biol Res Commun. 2(1): 64-70.

WERB Z, SYMPSON CJ, ALEXANDER CM, THOMASSET N, LUND LR, MACAULEY A (1996) Extracellular matrix remodeling and the regulation of epithelialstromal interactions during differentiation and involution. Kidney Int 54 (Suppl: S) 68-74.

WILKOWSKY SE, BARBIERI MA, STAHL P, ISOLA EL. (2001) Trypanosoma cruzi: phosphatidylinositol 3-kinase and protein kinase B activation is associated with parasite invasion. Exp Cell Res. 264(2): 211-8.

WIRTH JJ, KIERSZENBAUM F. (1984) Fibronectin enhances macrophage association with invasive forms of Trypanosoma cruzi. J Immunol. 133(1): 460-4.

WOOLSEY AM, BURLEIGH BA (2004) Host cell actin polymerization is required for cellular retention of Trypanosoma cruzi and early association with endosomal/lysosomal compartments. Cell Microbiol. 6(9): 829-38.

WORLD HEALTH ORGANIZATION. Control of Chagas' disease. Report of the WHO Expert Committee. World Health Organ Tech Rep Series (2002);905.

WORLD HEALTH ORGANIZATION Department of Control of Neglected Tropical Diseases www.who.int/neglected_diseases (2009)

YOSHIDA N. (2006) Molecular basis of mammalian cell invasion by Trypanosoma cruzi. An Acad Bras Cienc. 78(1): 87-111.

YOSHIDA N. (2008) Trypanosoma cruzi infection by oral route How the interplay between parasite and host components modulates infectivity. Parasitol Int 57(2): 105-9.

ZHONG L, LU HG, MORENO SN, DOCAMPO R. (1998) Tyrosine phosphate hydrolysis of host proteins by Trypanosoma cruzi is linked to cell invasion. FEMS Microbiol Lett. 161(1): 15-20. 